\title{
The Usefulness of Picture Consonant Articulation Test Determining the Effectiveness of Frenotomy in Ankyloglossia Patients
}

\author{
Soo Kweon Koo, Sung Hoon Jung, Young Jun Kim, and Young Joong Kim \\ Department of Otolaryngology-Head and Neck Surgery, Busan St. Mary's Hospital, Busan, Korea
}

\section{설소대 단축증 환자에서 그림 자음 검사의 유용성}

구수권 · 정성훈 · 김영준 · 김영중

부산성모병원 이비인후과

\author{
Received May 6, 2015 \\ Revised June 13, 2015 \\ Accepted June 17, 2015 \\ Address for correspondence \\ Soo Kweon Koo, MD, PhD \\ Department of Otolaryngology- \\ Head and Neck Surgery, \\ Busan St. Mary's Hospital, \\ 25-14 Yongho-ro 232beon-gil, \\ Nam-gu, Busan 48575, Korea \\ Tel +82-51-933-7214 \\ Fax +82-51-956-1956 \\ E-mail koosookweon@naver.com
}

Background and Objectives To determine the extent of speech articulation disorder in ankyloglossia patients and to determine whether picture consonant articulation test has potential as a screening test to predict the outcome of surgery.

Subjects and Method A total of 35 patients ( 25 boys and 10 girls with mean age of $3.69 \pm 1.18$ years) with ankyloglossia who underwent frenotomy and recovered completely without complications were enrolled in this study. We examined the correlation between the subjective satisfaction of parents and the results of picture consonant articulation test.

Results In the picture consonant articulation test, 20 patients $(20 / 35,57.14 \%)$ needed postoperative speech therapy. When the resutls of preoperative picture consonant articulation test and postoperative parents' subjective satisfaction were compared, "normal" had a satisfaction score of $4.53 \pm 0.74$ points, "consider" had $3.89 \pm 1.05$ points, and "demand" had $3.27 \pm 1.45$ points. When a postoperative speech therapy was required, parents' satisfaction decreased (correlation coefficient $\mathrm{r}=-0.456)$.

Conclusion The preoperative picture consonant test in our study showed potential as a screening test for predicting the outcome of surgery for ankyloglossia patients. Korean J Otorhinolaryngol-Head Neck Surg 2015;58(10):694-8

Key Words Ankyloglossia · Articulation disorder - Speech articulation test - Surgery.

\section{Introduction}

Ankyloglossia, also known as tongue tie, is a disease characterized by abnormally short frenulum. ${ }^{1)}$ It is a relatively common congenital disease with incidence ranging from $2.08 \%$ to $10.7 \%$ and a male to female ratio of $3: 1 .^{2-5)}$ The diagnosis and treatment as well as the symptoms of ankylogossia remain controversial among researchers. However, it is well known that ankyloglossia causes movement disorder of the tongue, resulting in lactation failure, speech articulation disorders, dysphagia, oral motor disorders, and respiratory dis- orders. ${ }^{6,7)}$ To correct ankyloglossia, tongue tie division, frenotomy is the mainstay surgery. However, there is no clear evidence on the effect of this surgical treatment. ${ }^{4,7-9)}$ The main purpose of the operation is to correct speech articulation disorder. During childhood, language acquisition is not complete. Therefore, objective inspection of speech articulation is very difficult. Picture consonant articulation test (PCAT) (Kim and Shin 2004) ${ }^{10)}$ is a test designed to assess the ability of a child to modulate consonant pronunciation while the child is naturally looking at a painting. The objectives of this study were to: 1) determine the extent of speech articulation disorder 
of ankyloglossia patients via the PCAT, and 2) determine whether PCAT has the potential as a screening test to predict the outcome of the surgery by comparing PCAT to postoperative subjective questionnaire.

\section{Subjects and Method}

A retrospective analysis was done in a single center between 2013 and 2014. And this study was approved by the Busan Saint Mary's Hospital Institutional Review Board.

\section{Subjects}

A total of 35 patients with ankyloglossia were enrolled. They underwent frenotomy and recovered completely without complications. The mean follow up period was over 1 month. All patients underwent history taking and ear, nose, throat examination as well as PCAT. Patients with other associated problem that might affect speech articulation such as cleft palate or developmental delay were excluded. We also excluded patients who underwent tonsillectomy or other additional surgery in addition frenotomy. Ankyloglossia was diagnosed if they satisfied the following two conditions at the same time. First, the length of the frenulum was within 25 to $100 \%$ of the tongue length, ${ }^{5)}$ second, frenulum of the tongue was abnormally thickened and distinctive heart shape was observed when the frenulum of tongue was held out. ${ }^{11)}$

\section{Operation method}

Surgery was performed under intravenous anesthesia. After lifting the frenulum of the tongue by tongue forceps, we observed the opening and the running of the submandibular duct to prevent damage to the submandibular duct during surgery. Additional local anesthesia was performed around the fibrous band of frenulum of tongue using 1:100000 epi- nephrine mixed with lidocaine solution. We separated a fibrous band by using metzenbaum scissors. We paid attention to the running of the submandibular duct during the closure of the mucosa of the cleavage plane with Vicryl 4-0 to ensure that there was no surgical bleeding.

\section{Parents' subjective questionnaire}

Telephone survey was done 1 month after the surgery. The questionnaire consisted of five items. Quantitative data regarding speech intelligibility was compiled using the Likert Scale 1-5 (1-Poor outcome, 3-Intelligible, 5-Well-developed). ${ }^{5)}$ After one month, parents were asked to consider vocabulary development, articulation, and impaired sounds when making their judgments regarding speech outcomes (Table 1).

\section{Picture consonant articulation test}

In a noise control room, each subject listened to the pronunciation of 30 words, including 43 phonemes used in the PCAT on the day before the surgery. Pronunciation of the subject was recorded $15 \mathrm{~cm}$ away from the microphone. The same examiner and one other expert heard it and decided it to be true or false. The number of phonemes correctly pronounced was expressed as a percentage (\%). ${ }^{10)}$ If the percentage was around the average of the same age, we defined it as "normal". If the result was between -1 standard deviation (SD) to -2 of the aver-

Table 1. Telephone questionnaire

1. Patient's information: age and sex
2. What is the most likleyresion is that to have surgery?
3. When did the patient received frenotomy?
4. After receiving the frenotomy, the patient's
pronunciation has improved?
4-1. Then Currently, the pronunciation score of the patient?
1
Poor

5. After receiving the frenotomy, did and side effect?

Table 2. Words used in picture consonant articulation test

\begin{tabular}{|c|c|c|c|c|}
\hline $\begin{array}{l}\text { Korean word of pants } \\
\text { [baji] }\end{array}$ & $\begin{array}{l}\text { Korean word of button } \\
\text { [danchu] }\end{array}$ & $\begin{array}{l}\text { Korean word of desk } \\
\text { [chaeksang] }\end{array}$ & $\begin{array}{l}\text { Korean word of bag } \\
\text { [gabang] }\end{array}$ & $\begin{array}{l}\text { word of candy } \\
\text { g] }\end{array}$ \\
\hline $\begin{array}{l}\text { Korean word of pencil } \\
\text { [yonpil] }\end{array}$ & $\begin{array}{l}\text { Korean word of car } \\
\text { [jadongcha] }\end{array}$ & $\begin{array}{l}\text { Korean word of zoo } \\
\text { [dongmulwon] }\end{array}$ & $\begin{array}{l}\text { Korean word of mom } \\
\text { [eomma] }\end{array}$ & $\begin{array}{l}\text { Korean word of kiss } \\
\text { [ppoppo] }\end{array}$ \\
\hline $\begin{array}{l}\text { Korean word of tiger } \\
\text { [horangi] }\end{array}$ & $\begin{array}{l}\text { Korean word of tail } \\
\text { [kkori] }\end{array}$ & $\begin{array}{l}\text { Korean word of elephant } \\
\text { [kokkiri] }\end{array}$ & $\begin{array}{l}\text { Korean word of peanut } \\
\text { [ttangkong] }\end{array}$ & $\begin{array}{l}\text { Korean word of ear } \\
\text { [gwi] }\end{array}$ \\
\hline $\begin{array}{l}\text { Korean word of swing } \\
\text { [geune] }\end{array}$ & $\begin{array}{l}\text { Korean word of rabbit } \\
\text { [tokki] }\end{array}$ & $\begin{array}{l}\text { Korean word of ballon } \\
\text { [pungseon] }\end{array}$ & $\begin{array}{l}\text { Korean word of robot } \\
\text { [robot] }\end{array}$ & $\begin{array}{l}\text { Korean word of picture } \\
\text { [geurim] }\end{array}$ \\
\hline $\begin{array}{l}\text { Korean word of nail } \\
\text { [mot] }\end{array}$ & $\begin{array}{l}\text { Korean word of eyebrow } \\
\text { [nunsseop] }\end{array}$ & $\begin{array}{l}\text { Korean word of monster } \\
\text { [goemul] }\end{array}$ & $\begin{array}{l}\text { Korean word of fight } \\
\text { [ssaum] }\end{array}$ & $\begin{array}{l}\text { Korean word of sparrow } \\
\text { [chamsae] }\end{array}$ \\
\hline $\begin{array}{l}\text { Korean word of three } \\
\text { [semari] }\end{array}$ & $\begin{array}{l}\text { Korean word of tweet } \\
\text { [jjaekjjaek] }\end{array}$ & $\begin{array}{l}\text { Korean word of tree } \\
\text { [namu] }\end{array}$ & $\begin{array}{l}\text { Korean word of locust } \\
\text { [mettugi] }\end{array}$ & $\begin{array}{l}\text { Korean word of telephone } \\
\text { [jeonhwa] }\end{array}$ \\
\hline
\end{tabular}


Table 3. Mean value of picture articulation consonant test

\begin{tabular}{|c|c|c|c|c|c|c|c|c|c|}
\hline \multirow{2}{*}{ Age } & \multicolumn{3}{|c|}{ Mean consonant accuracy } & \multicolumn{3}{|c|}{ ו SD } & \multicolumn{3}{|c|}{$-2 S D$} \\
\hline & Male & Female & Total & Male & Female & Total & Male & Female & Total \\
\hline 2 & 80.34 & 86.84 & 94.61 & 70.03 & 78.77 & 75.33 & 59.72 & 70.7 & 66.05 \\
\hline 3 & 91.75 & 92.58 & 92.25 & 84.19 & 87.88 & 86.39 & 76.63 & 83.18 & 80.53 \\
\hline 4 & 94.16 & 96.17 & 95.23 & 89.18 & 92.29 & 90.76 & 84.2 & 88.41 & 86.29 \\
\hline 5 & 98.26 & 96.27 & 97.46 & 95.71 & 92.42 & 94.23 & 93.16 & 88.57 & 91 \\
\hline 6 & 98.43 & 97.5 & 97.9 & 96.18 & 95.4 & 95.72 & 93.93 & 93.3 & 93.54 \\
\hline
\end{tabular}

By evaluating the number of words correctly pronounced, the result was expressed as a percentage (\%)

Table 4. Age and sex distribution of patient with ankyloglossia

\begin{tabular}{lccc}
\hline \multirow{2}{*}{ Age (year) } & \multicolumn{2}{c}{ Sex } & $\begin{array}{c}\text { Total } \\
\text { number }\end{array}$ \\
\cline { 2 - 3 } & Boys & Girls & 2 \\
3 & 1 & 1 & 19 \\
4 & 13 & 6 & 7 \\
5 & 6 & 1 & 3 \\
Over 6 & 2 & 1 & 4 \\
Mean age (years) & $3.76 \pm 1.20$ & $3.50 \pm 1.18$ & $3.69 \pm 1.18$ \\
\hline Total & 25 & 10 & 35
\end{tabular}

Table 5. Comparison between picture consonant articulation test result and postoperative subjective score

\begin{tabular}{lcc}
\hline \multicolumn{1}{c}{ Result of PCAT } & Number $(\%)$ & $\begin{array}{c}\text { Postop subjective } \\
\text { score (mean } \pm \text { SD) }\end{array}$ \\
\hline Normal & $15(42.9)$ & $4.53 \pm 0.74$ \\
Consider & $9(25.7)$ & $3.89 \pm 1.05$ \\
Demand & $11(31.4)$ & $3.27 \pm 1.49$ \\
\hline Total & $35(100)$ & $3.97 \pm 1.20$ \\
\hline PCAT: picture
\end{tabular}

PCAT: picture consonant articulation test, SD: standard deviation

age result, we defined it as "consider". If the result was less than -2 SD of the average result, we defined it as "demand". The groups of "consider" and "demand group" are the groups that needed speech therapy (Table 2 and 3). To predict whether PCAT has the potential as a screening test, we examined the correlation between the result of preoperative PCAT and postoperative subjective parental satisfaction.

\section{Statistical analysis}

All statistical analyses were performed using SPSS software (ver. 18.0, SPSS Inc., Chicago, IL, USA). We evaluated the correlation between preoperative PCAT and postoperative quantitative data regarding speech intelligibility using Pearson correlation test. Paired t-test was used to determine the differences between preoperative quantitative data regarding speech intelligibility and postoperative quantitative data. The null hypothesis of no difference was rejected if $p$ value was less than 0.05 . Results were presented as means $\pm \mathrm{SD}$.

\section{Results}

Thirty five children were enrolled in this study, including 25 boys and 10 girls. Their mean age was $3.69 \pm 1.18$ years old ( $3.76 \pm 1.20$ years for boys and $3.50 \pm 1.18$ years for girls) (Table 4 ). There was no postoperative complication. Subjective satisfaction of patient's parents was surveyed through a questionnaire that has been improved from preoperative ( $2.37 \pm 1.17$ points) to postoperative $(3.97 \pm 1.20$ points), which was statistically significant $(p<0.001)$.

In the PCAT, the number patients who were in the "normal", "consider", and "demand" groups was 15, 9, and 11, respectively. Therefore, a total of 20 patients $(20 / 35,57.14 \%)$ needed postoperative speech therapy. When preoperative PCAT was compared to postoperative parent's subjective satisfaction, "normal" had a satisfaction score of $4.53 \pm 0.74$ points, "consider" had $3.89 \pm 1.05$ points, and "demand" had $3.27 \pm 1.45$ points. Therefore, when postoperative speech therapy was required, parent's satisfaction score decreased (correlation coefficient $r=-0.456$ ) (Table 5, Fig. 1).

\section{Discussion}

Ankyloglossia is a relatively common congenital disease. "The assessment tool for lingual frenulum function" is an objective diagnostic criteria proposed by Hazelbaker. ${ }^{12)}$ It is consisted of five appearance items and seven functional items. Its usefulness and reliability has been verified. ${ }^{13)}$ However, ankyloglossia patients are too young to be easily applied clinically. For this reason, many researchers use a variety of criteria. In this study, ankyloglossia was diagnosed when the criteria proposed by the Hogan, et al. (a) (across the $20-100 \%$ of frenulum of tongue) and the criterion proposed by Griffiths ${ }^{11)}$ (abnormally thickened and showed heart shape when held out tongue) were simultaneously satisfied. Ankyloglossia can cause a varying degree of reduced tongue mobility associated with functional limitations, including breast feeding difficulties, atypical 


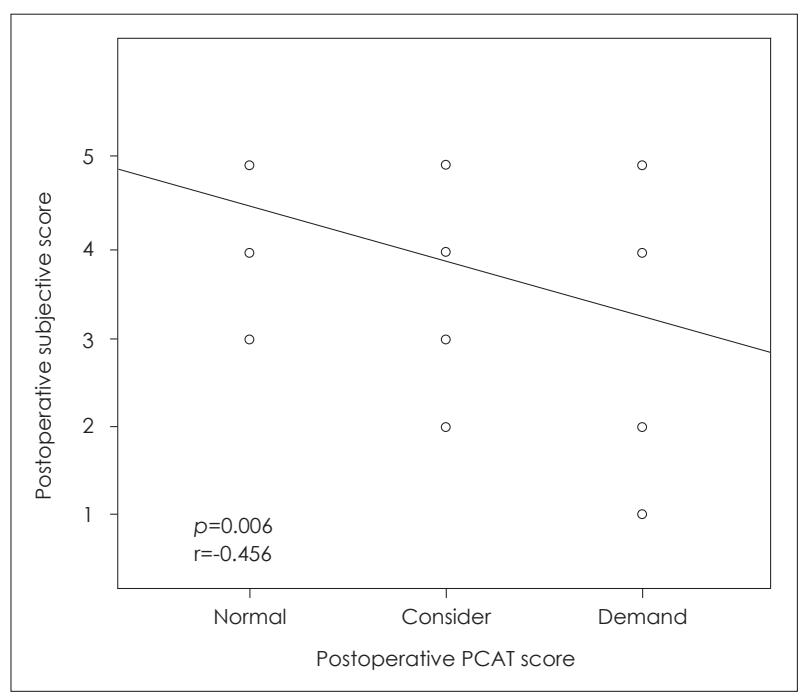

Fig. 1. Correlation between preoperative PCAT score and postoperative parent's satisfaction score. Normal: around the average of the same age, Consider: between -1 SD and -2 SD, Demand: lesser than -2 SD. Consider group and demand group needed speech therapy. When postoperative speech therapy was required, parent's satisfaction score decreased (correlation coefficient $r=-0.456$ ). PCAT: picture consonant articulation test, SD: standard deviation.

swallowing habits, speech articulation problems, mechanical problems such as inability to clean the oral cavity, and psychosocial stress. ${ }^{2)}$ According to Klockars and Pitkaranta ${ }^{13)}$ survey, $64 \%$ of patient visits for treatment wanted surgery due to speech articulation problem, whereas $18 \%$ who wanted the surgery was due to movement disorders of the tongue. In our study, all patients wanted surgery because of speech articulation problem. Thus, speech articulation problem is the most important therapeutic purposes in ankyloglossia patients. Surgical treatment of patients with ankyloglossia is classified into frenotomy, frenectomy, and frenoplasty. ${ }^{14)}$ However, some methods have not been established to be more useful. In this study, we used modified frenotomy method with absorbable material sealing in order to prevent re-adhesion of the cut frenulum of tongue because it is relatively simple and cost-effective. Surgical complications of ankyloglossia are rare. Bleeding at the surgical site has been reported to be $3-8 \%$, with re-attachment rate of $2-14 \%{ }^{15)}$ However, in our study, there was no complication. According to Messner, et al. ${ }^{2)}$ and Heller, et al. ${ }^{16)}$ study, there is improvement in speech articulation problem although some did not conduct a special speech therapy after the surgery. In another study, there was no statistically significant difference between treated children with fewer articulation errors and non-treated children. ${ }^{17)}$ In our study, subjective satisfaction of patient's parents was significantly improved from preoperative to postoperative. However, there is still controver- sy in surgical treatment. Speech articulation problem of ankyloglossia patients is very important. In surgical treatment of ankyloglossia patients, it is important to predict speech articulation problem by relying on subjective survey of parents in most cases because the patient is too young. Therefore, objective and formal test is very important. PCAT (Kim and Shin) ${ }^{10)}$ is a test designed to assess the ability of a child to modulate the consonant pronunciation while the child naturally tells what it is by looking at paintings. A total of 43 phonemes are evaluated by using 30 picture cards. Parents or inspector will check the pronunciation of the child. Results are obtained by calculating the pronunciation accuracy in percentile (by dividing the number of correct pronunciation of the phoneme by the total number of $43 \times 100$ ) compared to the normal percentage of children in the same age range. PCAT (Kim and Shin) ${ }^{10)}$ can help us diagnose articulation defects in children and provide a basis for speech therapy. Picture consonant test has some advantage and disadvantage. This test is available to check children whose language development is not complete. It is also possible to determine the treatment direction and to predict prognosis through test result. But, the words and language used differs according to age, there is a drawback which is not considered. The picture consonant screening test performed before surgery in our study showed potential as a screening test by showing correlation with postoperative parent's subjective satisfaction. The limitation of this study is that it did not consider the effects of postoperative speech therapy and the difference of language acquisition in accordance with the growth. To know only the effects of the surgery excluding the effect of postoperative speech treatment and the difference of language acquisition in accordance with the growth, we conducted a survey a month after the surgery that the surgical site has healed. However, language developmental processes or postoperative speech therapy are also an important factor, it should be considering future research.

\section{REFERENCES}

1) Catlin FI. Tongue-tie. Arch Otolaryngol 1971;94(6):548-57.

2) Messner AH, Lalakea ML, Aby J, Macmahon J, Bair E. Ankyloglossia: incidence and associated feeding difficulties. Arch Otolaryngol Head Neck Surg 2000;126(1):36-9.

3) Lalakea ML, Messner AH. Ankyloglossia: does it matter? Pediatr Clin North Am 2003;50(2):381-97.

4) Segal LM, Stephenson R, Dawes M, Feldman P. Prevalence, diagnosis, and treatment of ankyloglossia: methodologic review. Can Fam Physician 2007;53(6):1027-33.

5) Hogan M, Westcott C, Griffiths M. Randomized, controlled trial of division of tongue-tie in infants with feeding problems. J Paediatr Child Health 2005;41(5-6):246-50. 
6) Jung YJ, Moon SI, Han JW, Kim HK, Yoon SW, Kang KH. Effect of speech therapy on alveolar sound after lingual frenulotomy in tonguetie patients. Korean J Otolaryngol-Head Neck Surg 2001;44(3):317-25.

7) Lee HJ, Park HS, Park BS, Choi JW, Koo SK. The Improvement of Tongue Mobility and Articulation after Frenotomy in Patient with Ankyloglossia. Korean J Otorhinolaryngol-Head Neck Surg 2010;53 (8):491-6.

8) Hansen R, MacKinlay GA, Manson WG. Ankyloglossia intervention in outpatients is safe: our experience. Arch Dis Child 2006;91(6):541-2; author reply 542 .

9) Fleiss PM, Burger M, Ramkumar H, Carrington P. Ankyloglossia: a cause of breastfeeding problems? J Hum Lact 1990;6(3):128-9.

10) Kim YT, Shin MJ. Urimal Test of Articulation and Phonology (U-TAP). Seoul: Hakjisa;2004. p.31-50.

11) Griffiths DM. Do tongue ties affect breastfeeding? J Hum Lact 2004; 20(4):409-14
12) Amir LH, James JP, Donath SM. Reliability of the hazelbaker assessment tool for lingual frenulum function. Int Breastfeed J 2006; 1(1):3.

13) Klockars T, Pitkäranta A. Pediatric tongue-tie division: indications, techniques and patient satisfaction. Int J Pediatr Otorhinolaryngol 2009;73(10):1399-401.

14) Suter VG, Bornstein MM. Ankyloglossia: facts and myths in diagnosis and treatment. J Periodontol 2009;80(8):1204-19.

15) Messner AH, Lalakea ML. Ankyloglossia: controversies in management. Int J Pediatr Otorhinolaryngol 2000;54(2-3):123-31.

16) Heller J, Gabbay J, O’Hara C, Heller M, Bradley JP. Improved ankyloglossia correction with four-flap Z-frenuloplasty. Ann Plast Surg 2005;54(6):623-8

17) Dollberg S, Manor Y, Makai E, Botzer E. Evaluation of speech intelligibility in children with tongue-tie. Acta Paediatr 2011;100(9):e125-7. 